\title{
ANALYSIS OF TRACTION PROPERTIES AND POWER OF WHEELS USED ON VARIOUS AGRICULTURAL SOILS
}

\author{
Jarosław Czarnecki, Marek Brennensthul, Włodzimierz Białczyk, Weronika Ptak, \\ Łukasz Gil \\ Institute of Agricultural Engineering, University of Life Sciences in Wroclaw \\ *Corresponding author: e-mail: jaroslaw.czarnecki@upwr.edu.pl
}

\begin{tabular}{|c|c|}
\hline ARTICLE INFO & ABSTRACT \\
\hline $\begin{array}{l}\text { Article history: } \\
\text { Received: January } 2019 \\
\text { Received in the revised form: } \\
\text { February } 2019 \\
\text { Accepted: March } 2019 \\
\end{array}$ & \multirow{2}{*}{$\begin{array}{l}\text { The paper presents results of the research on traction properties of two } \\
\text { tractor tyres used on two agricultural grounds. The first ground was } \\
\text { a stubble and the second one cropland. The investigated tyres had the } \\
\text { same structure (diagonal, with a traditional tyre tread but different ex- } \\
\text { ternal dimensions. The research was carried out in field conditions with } \\
\text { the use of a stand aggregated with a farm tractor. Analysis covered trac- } \\
\text { tion efficiency, slide, towing power and power lost on the rolling re- } \\
\text { sistance and wheel slide. Based on the obtained results it was concluded } \\
\text { that on a ground with lower compaction, the values of power losses } \\
\text { were higher and traction efficiency was lower. Moreover, it was proved } \\
\text { that the value of the power lost for rolling resistance had a decisive im- } \\
\text { pact on the values of traction efficiency. }\end{array}$} \\
\hline $\begin{array}{l}\text { Key words: } \\
\text { farm tractor, } \\
\text { traction, } \\
\text { towing power, } \\
\text { traction efficiency, } \\
\text { power }\end{array}$ & \\
\hline
\end{tabular}

\section{Introduction}

Nowadays farm tractors are a universal source of traction energy in agriculture; they may be used for field and transport works. Their universality results in a great variability of traction forces including variability of the nature of energy losses in the wheel-ground system. These losses may result in two negative phenomena: wheel slide and rolling resistance. It is obvious that on grounds with varied properties, proportions between particular types of losses will be different. It should be emphasised that energy losses in the wheel-ground system have negative effects, which should be considered in two aspects: ecological (destruction of the ground structure) and economic (increased fuel consumption). Thus, investigation of the nature of losses in the wheel-ground base is justified.

Based on the analysis of literature it was proved that traction efficiency is often used to describe the cooperation conditions of a tractor wheel with a ground. (Battiato et al., 2017; Rosca et al., 2004; Wolf et al., 1996; Grisso et al., 1992; Simikić et al., 2012; Batiatto, Diserens, 2017). This parameter defines what part of the power supplied to a wheel was recovered in the form of the towing power (Zoz et al., 2003; Jakliński, 2006; Goering et al., 2004). Unfortunately, traction efficiency enables estimation of only total losses and does not enable indication which of the types of losses prevailed. Such analysis may be performed with the use of the power balance supplied to a wheel. This balance determined the values of the utility 
power (towing), power lost on the rolling resistance and power lost on sliding (Zoz et al., 2003; Materek, 2004; Ekinci et al., 2015).

\section{Objective and scope of research}

The reasons presented in the introduction resulted in studies the aim of which was to compare the traction properties of two tyres with varied mechanical properties used on grounds. Detailed objectives included as follows:

- compared values of traction efficiency and a nature of its changes as a function of wheel slide,

- assessment of proportions between element powers (determination of the power losses value),

The object of the research were traction properties of driving wheels designed for a farm tractor. It was assumed that these wheels were equipped with tyres of various external dimensions.

According to the assumed objective, assessment of the traction properties was carried out in two types of agricultural grounds. Non-compacted soil without a plant cover was the first ground. This soil was located on an experimental field at the Institute of Agricultural Engineering of the University of Life Sciences in Wroclaw. The second ground was a stubble after winter wheat cultivation. The stubble comprised experimental fields of IUNG in JelczLaskowice near Wroclaw in Dolnośląskie Voivodeship.

Before starting tractions studies, the condition of the grounds was defined by measurement of the water content, compaction, and resistance of static stresses. The obtained results were presented in table 1.

Table 1.

Parameters of grounds, on which the research was carried out

\begin{tabular}{llccc}
\hline & & \multicolumn{3}{c}{ Parameter } \\
\cline { 3 - 4 } Ground & Soil type & $\begin{array}{c}\text { Moisture } \\
(\%)\end{array}$ & $\begin{array}{c}\text { compaction } \\
(\mathrm{MPa})\end{array}$ & $\begin{array}{c}\text { Resistance to } \\
\text { static stresses } \\
(\mathrm{kPa})\end{array}$ \\
\hline Cultivation soil & Loamy sand & 19,7 & 0,76 & 62 \\
Stubble & Light sandy loam & 21,4 & 1.26 & 91 \\
\hline
\end{tabular}

Pursuant to the data presented in table 1 , a stubble was most resistant. Its compaction was higher than $65 \%$ in comparison to soil; in case of shear stresses the difference was $47 \%$.

The traction tests covered tyres 7.5-16 and 8.3-20 designed for farm tractors of lower towing classes. In both bases these were tube tyres with diagonal and classical tread, but they differed with external diameters. Structural and exploitation of tyres was presented in table 2 . 
Analysis of traction properties...

Table 2.

The list of parameters of investigated tyres

\begin{tabular}{lcccccc}
\hline $\begin{array}{l}\text { Symbols } \\
\text { of the tyre }\end{array}$ & $\begin{array}{c}\text { External } \\
\text { diameter } \\
(\mathrm{mm})\end{array}$ & $\begin{array}{c}\text { Diameter } \\
\text { of mounting } \\
(\mathrm{mm})\end{array}$ & $\begin{array}{c}\text { Width } \\
(\mathrm{mm})\end{array}$ & $\begin{array}{c}\text { Height } \\
\text { Of } \\
\text { Tread plys } \\
(\mathrm{mm})\end{array}$ & $\begin{array}{c}\text { Maximum } \\
\text { load } \\
(\mathrm{kg})\end{array}$ & $\begin{array}{c}\text { Maximum } \\
\text { air } \\
\text { pressure } \\
(\mathrm{MPa})\end{array}$ \\
\hline $7.5-16$ & 710 & 406 & 190 & 30 & 775 & 0.325 \\
$8.3-20$ & 845 & 510 & 210 & 35 & 900 & 0.200 \\
\hline
\end{tabular}

During the tests, one level of vertical load of wheel amounting to $6110 \mathrm{~N}(622.8 \mathrm{~kg})$ was used and one level of air pressure in tyres $(0.15 \mathrm{MPa})$. These values were pursuant to the catalogue recommendations of tyre producers.

\section{Research methodology}

Compaction and water content of grounds was measured with Penetrologger; grounds' resistance to static stresses was determined with a probe VANE H60 by Eijkelkamp. Each measurement was made in 5 iterations after which arithmetic means were calculated. Water content was measured at the depth of $0.05 \mathrm{~m}$, while compaction and resistance to static stresses - within the depth $0-0.15 \mathrm{~m}$.

Traction properties were determined with the use of a specialist test stand made in the Institute of the University of Life Sciences in Wroclaw. This stand was aggregated with a farm tractor. View of the test stand was presented in Figure 1.

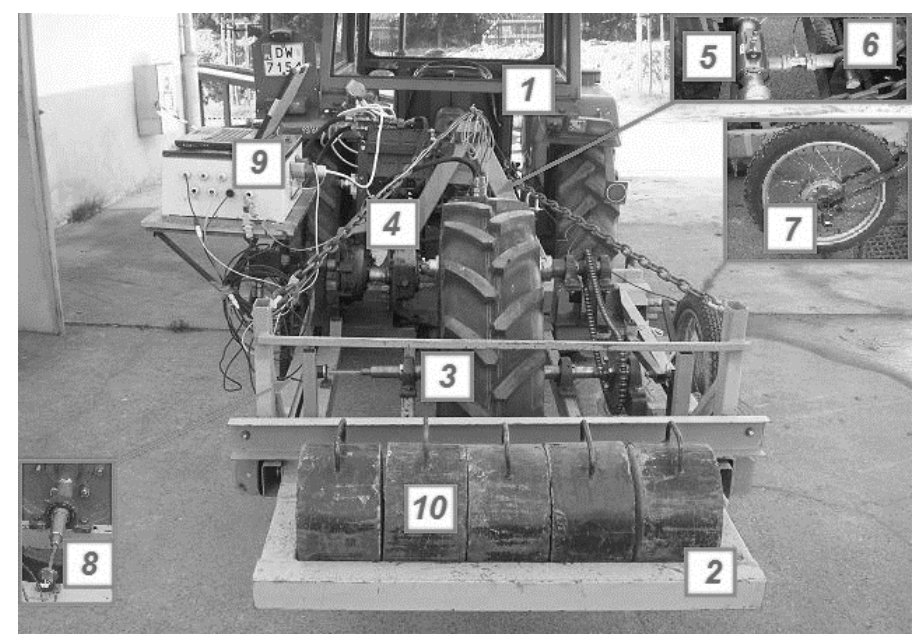

Figure. 1. Stand for determination of traction properties: 1 - farm tractor, 2 - frame, 3 - shaft with investigated wheel, 4 -drive gear, 5 - torque measuring shaft, 6 -dynamometer, 7 - sensor of real speed measurement, 8 - sensor of theoretical speed measurement, 9 - electronical registering unit, 10 - sinkers 
All elements of the stand (Fig.1) were mounted on a two-part frame (2) suspended on a three-point suspension system of a tractor (1). Between a front and a back part of a frame, dynamometer TecSis with a precision of measurement of $40 \mathrm{~N}$ and the measuring scope $0-20000 \mathrm{~N}$ (6) was mounted for measurement of the towing power. The tested wheel was mounted on a shaft (3); the wheel drive was obtained from the power take-off shaft through a reducing gear (4). Between a gear and a wheel there was an inductive torque measuring shaft installed with a precision of measurement of $1 \mathrm{Nm}$ within the range of $0-3000 \mathrm{Nm}$ (5). On the stand, there were also installed sensors for measurement of the real (7) and theoretical (8) speed. The test consisted in introduction of a wheel in motion and then relocation of a stand and simultaneous measurement of the selected traction parameters. Data measured by sensors were sent to an electronic registering unit (9). Each measurement was made in 5 iterations after which arithmetic means were measured.

Based on the measured values (towing power $P_{u}$, of the torque $M_{O}$ and real speed $v_{r}$ and theoretical $v_{t}$ ) values of the remaining parameters were calculated according to formulas 1-8.

$$
\begin{gathered}
\delta=100 \cdot\left(1-\frac{v_{r}}{v_{t}}\right) \\
P_{T}=\frac{M_{O}}{r} \\
P_{f}=P_{T}-P_{u} \\
\eta=\frac{P_{u}}{P_{T}} \cdot(100-\delta) \\
N_{k}=P_{T} \cdot v_{t} \\
N_{u}=P_{u} \cdot v_{R} \\
N_{f}=P_{f} \cdot v_{R} \\
N_{s}=P_{T} \cdot\left(v_{t}-v_{r}\right)
\end{gathered}
$$

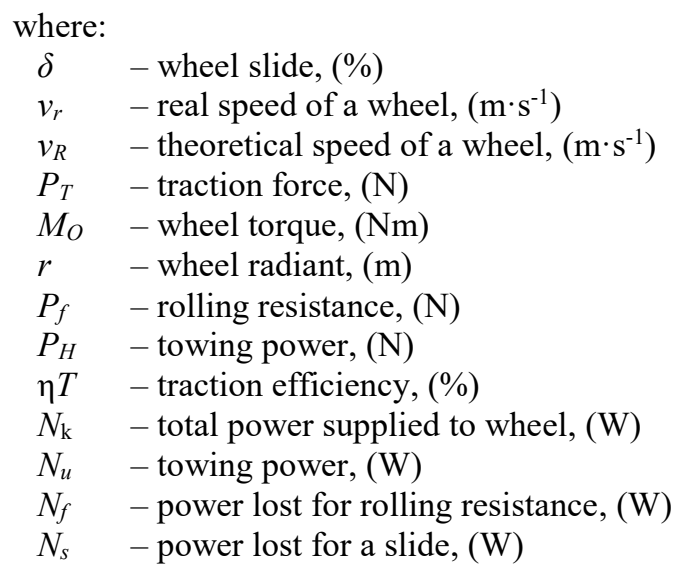


Analysis of traction properties...

The obtained results were subjected to statistical analysis with the use of Statistica 12.5. After the conditions of usability were verified, a two - way ANOVA was carried out at the significance level of $\alpha=0.05$.

\section{Results of the research}

First of the considered parameters was traction efficiency. Figure 2 presents courses of this parameter as the function of a wheel slide. The diagram shows that in all four cases the highest increase of traction efficiency as a function of slide took place at its low values (within $0-3 \%$ ). After the maximum was achieved, a slow decrease of the values of efficiency took place, which is compliant to the result presented in literature (Grisso et al., 1992; Zoz et al., 2003; Wulfsohn et al., 2009; Rosca et al., 2004). Both for a tyre 7.5-16, and 8.3-20, lower values of traction efficiency were observed on soil. One may assume that on this ground higher losses occurred related to deformation of the ground and wheel slide.

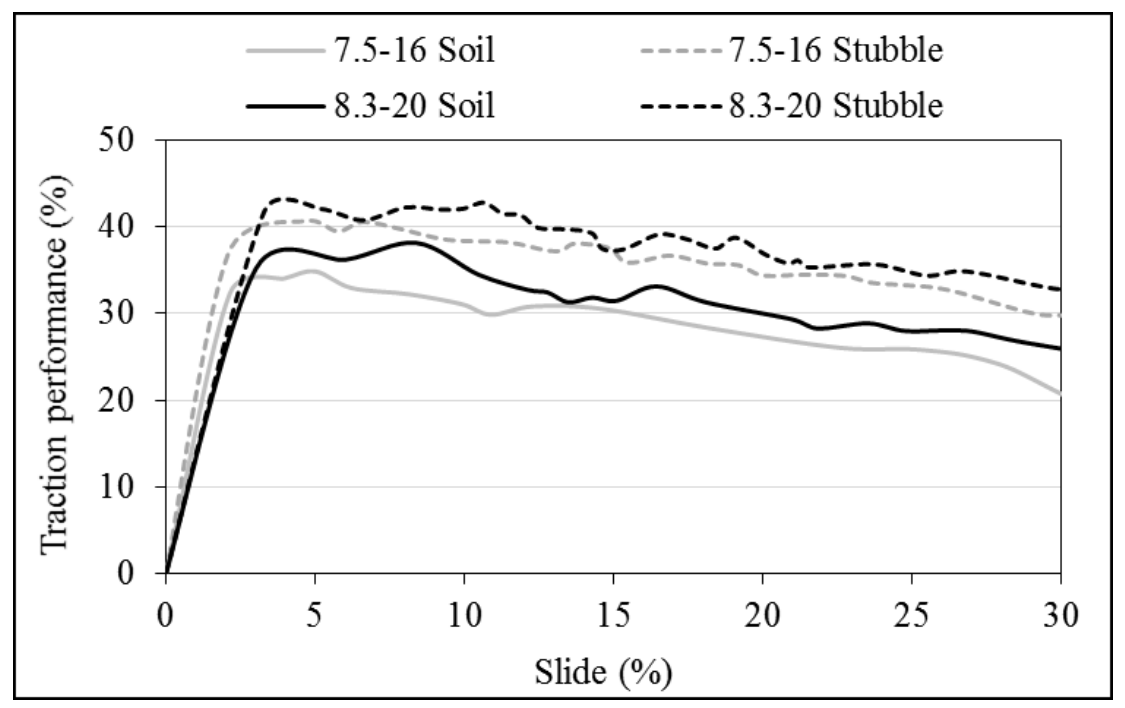

Figure 2. Courses of traction efficiency as the function of wheel slide

Nature of changes of the performance value on stubbles is similar to the results presented by Bashford et al., $(1993 ; 1999)$ - in the papers it they proved that the maximum values of traction efficiency took place at slides that did not exceed $8 \%$. However, in the papers by Jenane et al., (1995) and Simikić et al., (2012) maximum values of efficiency on a stubble corresponded to higher slides (10-15\%). When analysing the courses of performances on soil one may notice that some authors indicated that the maximum value of traction efficiency was achieved at higher slides, in papers by Grisso et al., (1992), Bashford et al., (1999), Wulfsohn et al., (2009) the maximum traction on soils takes place at slides $10-15 \%$. Higher 
values of efficiency on a stubble are confirmed in the available literature, where it is concluded that on grounds with higher compaction values of traction efficiency, they are higher (Jenane et al., 1996; Senatore et al. 2011). Comparison of both tyres proved that higher values of traction efficiency corresponded to a tyre 8.3-20 which is confirmed in the papers by Grisso et al., (1992), Bashford et al., (1999) where it was proved that a tyre with a bigger diameter achieves higher value of traction efficiency.

Values of component powers were presented in the function of wheel slide as in case of traction efficiency. Figure 3 presents courses of power for wheels with a tyre 7.5-16.

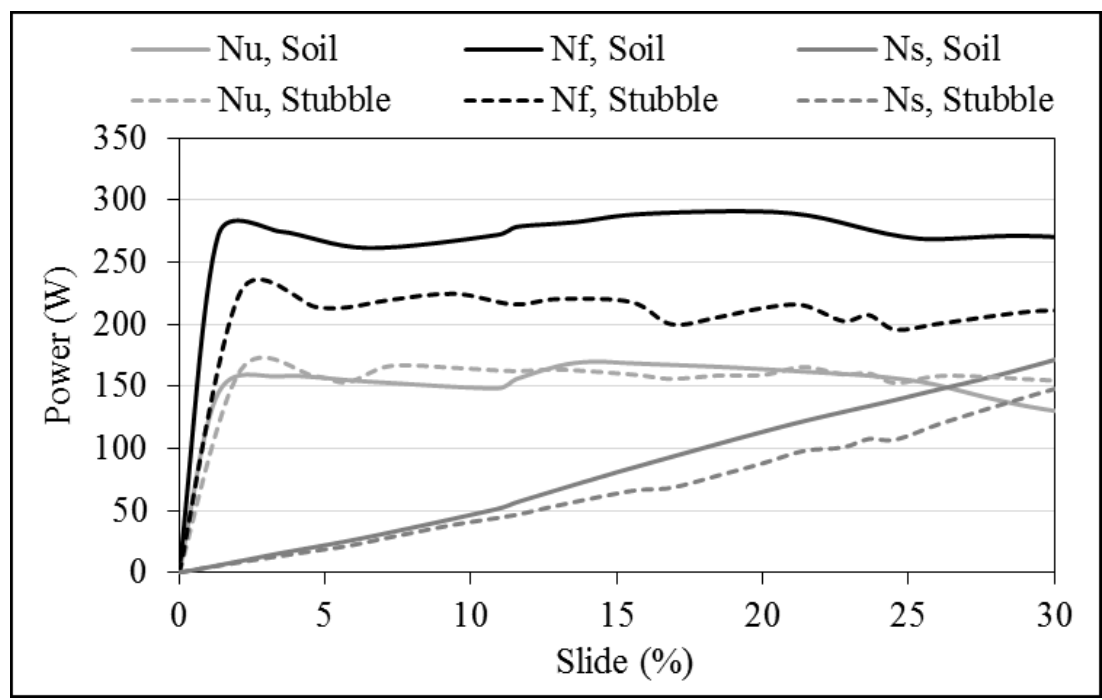

Figure 3. Courses of component powers of a wheel with tyre 7.5-16 on both grounds

According to the above diagram, a wheel with a tyre 7.5-16 had similar values of towing power on a stubble and soil - this trend took place in the entire analysed range of slide. Big differences took place in case of power lost on the rolling resistance - higher values of this parameter occurred on soil, differences achieved up to $40 \%$. Certainly, it resulted from lower resistance of this ground and as a result bigger vertical deformation. Power lost on slide on both grounds has similar courses and the increase of this power is proportional to the slide increment. Slightly higher values of the power lost on slide were reported in soil. They could have resulted from the presence of the post-harvest residues on a stubble which prevented slide.

Figure 4 presents the courses of element power of a wheel equipped with a tyre 8.3-20. 
Analysis of traction properties...

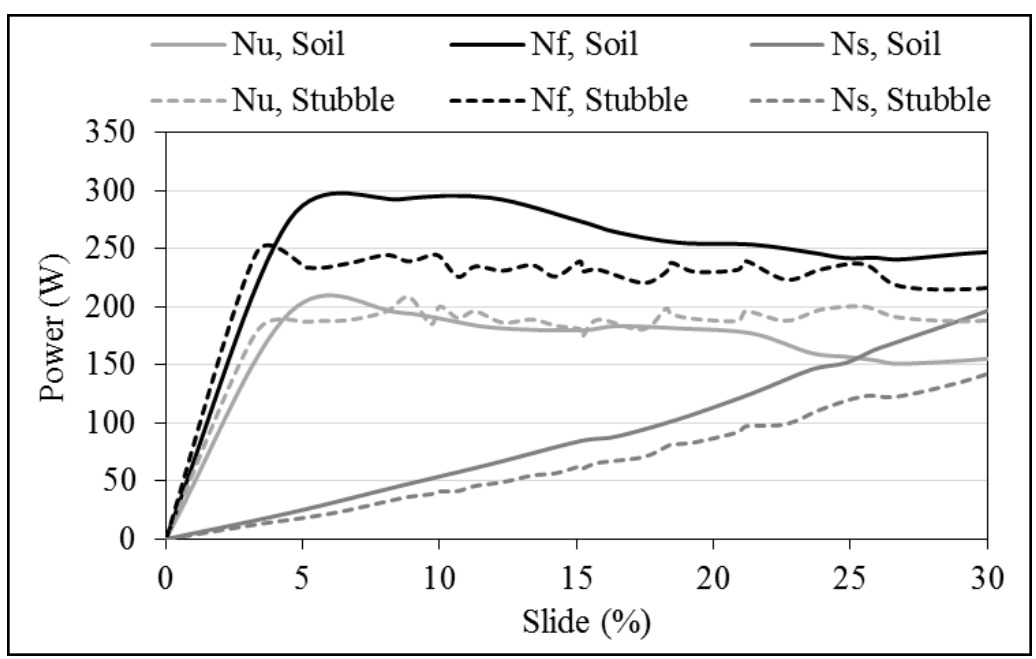

Figure 4. Courses of element powers of a wheel with a tyre 8.3-20 on both grounds

Analysis of courses of the towing power of a wheel with a tyre 8.3-30 enables conclusion that within the range of slides $0-20 \%$, no clear differences in the values of power on both grounds occurred. Only at higher slides, higher values of the towing power took place on a stubble. A reverse situation takes place in case of power lost on the rolling resistance- the biggest differences in values of this parameter were reported at slides 3-20\%; higher values of this power occurred on soil. The courses of power lost on slide are remarkably similar as in case of a wheel with a tyre 7.5-16 - higher losses on a slide occurred in soil.

The obtained results partially refer to the results presented by other researchers. The nature of changes of the course of power lost on slide and rolling resistance seems to be related to the paper by Materka (2004) and Turner (1995). In other papers authors showed that stabilization of the course of the towing power takes place at slides 15-20\% (Jenane et al., 1996; Materek, 2008).

To compare the values of component powers of both tyres on both grounds, average values for the entire range of the slide were calculated. Figure 5 presents a set of these values.

Analysis of the above diagram makes us conclude that both tyres achieved higher values of the towing power on a stubble in case of a tyre 7.5-16 a difference between the power on a stubble and ground was $5 \%$ while for the tyre $8.3-20-8 \%$. Higher values of losses related to the rolling resistance were reported in case of exploitation of tyres on soil; for a tyre 7.5-16 losses on soil were by $29 \%$ higher than on a stubble, for the second tyre, this difference was $15 \%$. The value of power lost on slide on soil was higher than on a stubble - for both tyres this difference was $22 \%$. Comparison of both tyres showed that a tyre 8.3-20 had higher values of the towing power and lower losses. Moreover, this tyre showed smaller difference in the values of the power lost on the rolling resistance on both tyres. Presumably, it results from a bigger surface area of the contact of this tyre with ground and as a result from smaller tendency of a tread to sink in ground. Such relation is compliant with the results obtained by other authors, who showed that tyres with bigger external dimensions have better traction properties (Grisso et al., 1992; Bashford et al., 1999). 
J. Czarnecki, M. Brennensthul, W. Białczyk, W. Ptak, Ł. Gil

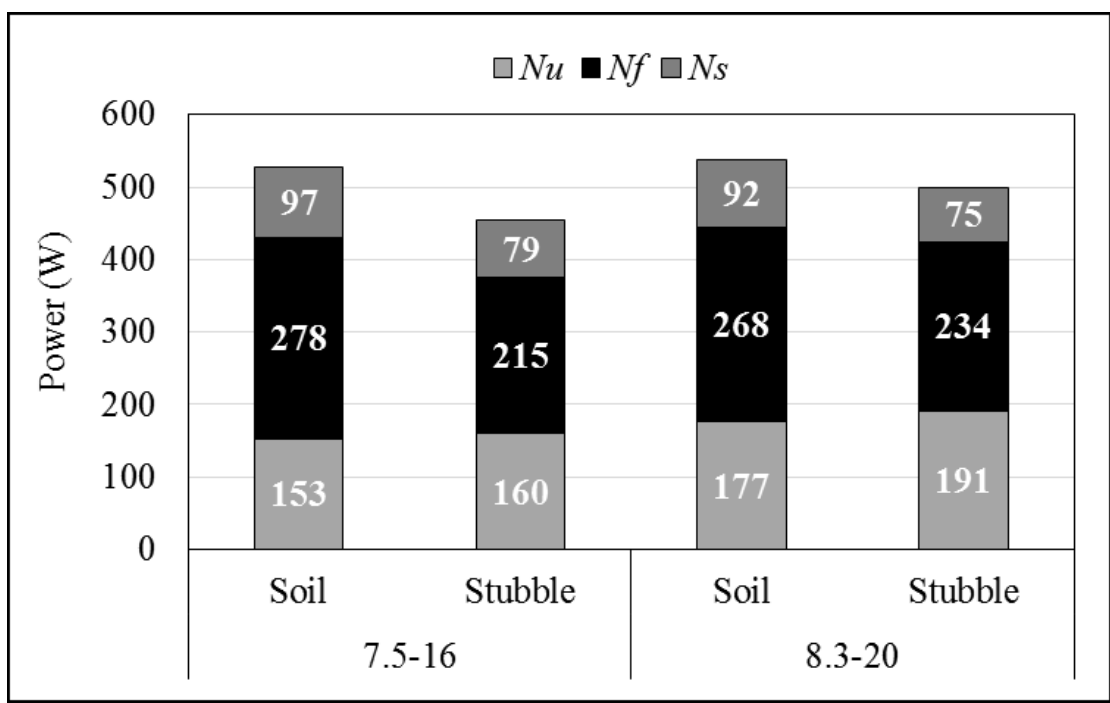

Figure 5. Set of average values of component powers at slides within 0-30\%

Since the value of the total powers (total component powers) of tested wheels on grounds was varied, analysis of the component powers participation seems to be justified in component powers. Figure 6 present a set of these values.

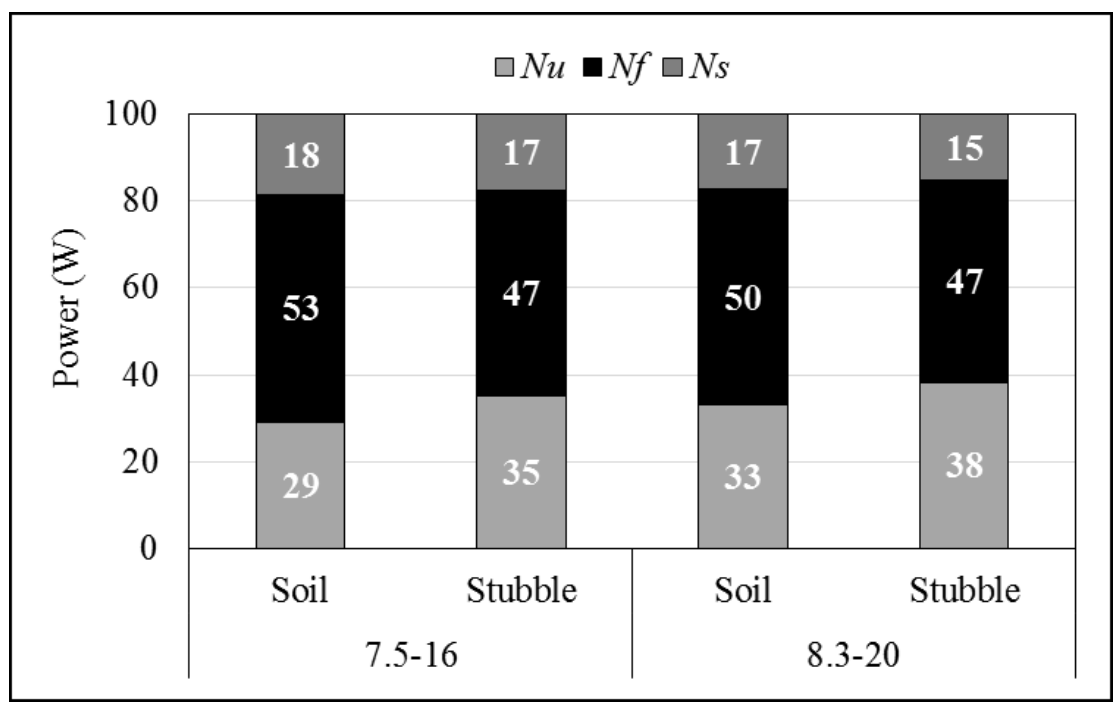

Figure 6. Set of component powers participation in the total power 
Analysis of traction properties...

Analysis of the above diagram enables conclusion that both tyres had higher towing power participation on a stubble which justifies the fact that higher values of the traction efficiency were obtained on this ground. Lower participation of power consumed for the rolling resistance also occurred on this ground. At the same time, we may see that participation of the power lost on slide on a stubble is only slightly lower than on soil. Based on this, we may say that the size of the power lost on the rolling resistance mostly decides on the traction efficiency.

The obtained results were subjected to two-way analysis of variance at the level of significance $\alpha=0.05$. Table 3 presents results of the analysis.

Table 3.

Results of statistical analysis

\begin{tabular}{lcccc}
\hline \multirow{2}{*}{ Factor } & \multicolumn{4}{c}{ Values $p$ for $\alpha=0.05$} \\
\cline { 2 - 5 } & $\begin{array}{c}\text { Traction } \\
\text { efficiency }\end{array}$ & $\begin{array}{c}\text { Towing } \\
\text { power }\end{array}$ & $\begin{array}{c}\text { Power lost } \\
\text { for rolling resistance }\end{array}$ & $\begin{array}{c}\text { Power lost } \\
\text { for slide }\end{array}$ \\
\hline $\begin{array}{l}\text { Size } \\
\text { of the tyre }\end{array}$ & 0.000002 & $<0.000001$ & 0.376894 & 0.000909 \\
\hline $\begin{array}{l}\text { Type } \\
\text { of ground }\end{array}$ & $<0.000001$ & 0.000473 & 0.000006 & $<0.000001$ \\
\hline
\end{tabular}

Values presented in table 3 describe the level of probability of rejection of a hypothesis that says that there is no significant impact on the given factor. If value $p$ is higher than the assumed level of significance, then a given factor has no significance impact on the considered parameter. The analysis that was carried out proves that the ground type had a significant effect on all analysed parameters while dimension of the tyre had no impact on the sizes of the power lost for rolling resistance.

\section{Conclusions}

Based on the obtained results of research, the following conclusions were made:

1. Mechanical properties of the ground determine the values of traction efficiency of wheels which were used on this ground. Higher values of traction efficiency were achieved on this ground with lower deformation. No impact of the ground type and wheels size on the nature of changes in efficiency as the function of slide was observed.

2. The nature of changes of the towing power as the function of wheel slide is different for grounds; the course of the towing power is more stable on a stubble than on soil.

3. Analysis of power losses proved that the power lost on the rolling resistance of a wheel has a predominant effect on the traction efficiency. The value of this power and its percentage participation in the total power showed the highest variability in relation to the ground.

4. Comparison of the size of tyres in the aspect of achieved traction efficiencies proved that a tyre with a bigger diameter and width had better traction properties. 


\section{References}

Bashford, L.L., Al-Hamed, S., Jenane, C. (1993). Effects of tire size and inflation pressure on tractive performance. ASAE Paper, 92(1011), 343-348.

Bashford, L.L., Kocher, M.F., Tibbetts, T.S. (1999). Wide tires, narrow tires. Biological Systems Engineering: Papers and Publications, Paper 174, 1-7.

Battiato, A., Diserens, E. (2017). Tractor traction performance simulation on differently textured soils and validation: A basic study to make traction and energy requirements accessible to the practice. Soil \& Tillage Research, 166, 18-32.

Ekinci, S., Çarman, K., Kahramanl1, H. (2015). Investigation and modelling of the tractive performance of radial tyres using off-road vehicles. Energy, 93, 1953-1963.

Goering, C.E. Hansen, A.C. (2004). Engine and Tractor Power. ASAE Publication.

Grisso, R.D., Taylor, R.K., Way, T.R. (1992). Tractive performance of $18.4 R 46$ and 18.4 R42 radial tractor tires. ASAE Paper, 91(1589), 739-745.

Jakliński, L. (2006). Mechanika układu pojazd - teren w teorii i badaniach. Wybrane zagadnienia. Oficyna Wydawnicza Politechniki Warszawskiej. ISBN 83-7207-595-6.

Jenane, C., Bashford, L.L. (1995). Field tractive performance comparisons between a tractor operated in the 2WD and 4WD mode. Actes. Inst. Agron. Vet. 15(1), 47-54.

Jenane, C., Bashford, L.L., Monroe, G. (1996). Reduction of fuel consumption through improved tractive performance. Journal of Agricultural Engineering Research, 64, 131-138.

Materek, D. (2004). Analiza właściwości trakcyjnych kołowego ciągnika rolniczego w wybranych technologiach uprawy roślin. Zeszyty Naukowe Akademii Rolniczej we Wrocławiu.

Materek, D. (2008). Analiza wybranych właściwości trakcyjnych ciągnika John Deere 7720. Inżynieria Rolnicza, 5(103), 127-130.

Rosca, R., Rakosi, E., Manolanche, G. (2004). Wheel traction prediction on agricultural soil. In: Mat. Konf. Aktualni zadaci mehanizacije poljoprivrede. Zbornik radova, 32. međunarodnog simpozija iz područja mehanizacije poljoprivrede. 23-27 Februar. Opatija, Hrvatska, 71-79.

Senatore, C., Sandu, C. (2011). Off-road tire modeling and the multi-pass effect for vehicle dynamics simulation. Journal of Terramechanics, 48, 265-276.

Simikić, M., Dedović, N., Savin, L. (2012). Influence of eccentric drawbar force on power delivery efficiency of a wheeled tractor. Turkish Journal of Agricultural and Forestry, 36, 1-16.

Turner, R. J. (1995). Comparison of two and four track machines to rubber tire tractors in prairie soil conditions. SAE Technical Paper Series, 952097, 1-14.

Wolf, D., Shmulevich, I., Mussel, U. (1996). Wheel traction prediction on hard soil. ASAE Paper, 92(1012), 1275-1283.

Wulfsohn, D., Way, T. R. (2009). Factors that influence tractive performance of wheels, tracks and vehicles. Advances in Soil Dynamics - St Joseph Michigan ASABE. 3, 209-252.

Zoz, F.M., Grisso, R.D. (2003). Traction and tractor performance. ASAE Distinguished Lecture Series, Tractor Design No 27, publication number 913C0403. 


\section{ANALIZA WLAŚCIWOŚCI TRAKCYJNYCH ORAZ MOCY KÓE EKSPLOATOWANYCH NA RÓŻNYCH PODLOŻACH ROLNICZYCH}

Streszczenie. W pracy przedstawiono wyniki badań właściwości trakcyjnych dwóch opon ciągnikowych eksploatowanych na dwóch podłożach rolniczych. Pierwszym podłożem było ściernisko, natomiast drugim gleba uprawna. Badane opony posiadały taka samą konstrukcję (diagonalne, o klasycznej rzeźbie bieżnika), lecz odmienne wymiary zewnętrzne. Badania przeprowadzono warunkach polowych z wykorzystaniem stanowiska agregatowanego z ciągnikiem rolniczym. Analizowanymi właściwościami były sprawność trakcyjna, poślizg, moc uciągu oraz moce tracone na opór przetaczania i poślizg koła. Na podstawie uzyskanych wyników stwierdzono, że na podłożu o mniejszej zwięzłości wartości strat mocy były wyższe, a sprawność trakcyjna niższa. Ponadto wykazano, że wartość mocy traconej na opór przetaczania miała dominujący wpływ na wartości sprawności trakcyjnej.

Słowa kluczowe: ciągnik rolniczy, trakcja, siła uciągu, sprawność trakcyjna, moc

Identification data Authors:

Jarostaw Czarnecki

https://orcid.org/0000-0001-7086-1525

Włodzimierz Białczyk https://orcid.org/000-0002-7710-0371

Marek Brennensthul https://orcid.org/0000-0003-4964-482X

Ptak Weronika

Gil Łukasz 